\title{
Active role of flower shops in the commercialization of roses
}

\author{
Nereida Rodríguez Orozco ${ }^{1^{*}}$ (D), Emmanuel Vázquez Anastasio ${ }^{1}$ (D), \\ Ariadna Linares Gabriel ${ }^{2}$ (D), Mario Alejandro Hernández Chontal ${ }^{1}$ (D) \\ ${ }^{1}$ Universidad Veracruzana, Facultad de Ciencias Agrícolas, Xalapa, México. \\ ${ }^{2}$ Independent Researcher, Veracruz, México
}

\begin{abstract}
Retail florist activities are essential elements in the rose (Rosa spp.) market since they generate significant income and employment. In these jobs, florists gain recognition by their designs that captivate consumers. At the same time, they are key entrepreneurs in the commercialization of roses. Then, the objective of the research was to know the entrepreneurial role of florists in the commercialization of roses (Rosa spp.) in southern Veracruz, Mexico. An exploratory research was conducted in flower shops, five in Coatzacoalcos, nine in Minatitlán and six in Acayucan. Interviews were conducted with florists $(n=20)$. The categories of analysis used were the demographic, psychosocial and sociocultural profile of the florists as innovative entrepreneurs. In regards to the demographic profile, these economic agents have the experience and knowledge necessary to develop their activity. In short, florists are identified as family micro-enterprises with establishments that are 20 years old. In the psychosocial profile, florists present low innovative capacity with respect to the composition of their floral arrangements; however, they are characterized as risk takers with the ability to solve problems. Finally, the sociocultural profile demonstrates the florists-intermediary-producers collaboration; such entrepreneurial activity generates economic incentives with local-regional influence. Therefore, florists need to strengthen their links with other florists, producers and distributors to improve their innovative capabilities that will benefit both themselves and consumers.
\end{abstract}

Keywords: entrepreneurs, innovation, Rosa spp., florists, flower arrangements

\section{Resumo}

Papel ativo das floriculturas na comercialização de rosas

As atividades de varejo são essenciais no comércio de rosas (Rosa spp.), uma vez que geram rendimentos e empregos significativos. Nestes trabalhos, os floristas ganham reconhecimento pelos seus arranjos que conquistam os consumidores. Ao mesmo tempo, são empreendedores chave na comercialização de rosas. O objetivo dessa pesquisa foi identificar o papel empresarial dos floristas na comercialização de rosas (Rosa spp.) no sul de Veracruz, México. Foi realizada uma pesquisa exploratória em floriculturas, cinco em Coatzacoalcos, nove em Minatitlán e seis em Acayucan. Foram conduzidas entrevistas com 20 floristas. As categorias de análise utilizadas foram o perfil demográfico, de psicossocial e sociocultural dos floristas como empresários inovadores. Quanto ao perfil demográfico, estes agentes econômicos têm a experiência e o conhecimento necessários para desenvolver a sua atividade. Em suma, os floristas são identificados como microempresas familiares com estabelecimentos com 20 anos de atuação. No perfil psicossocial, os floristas apresentam baixa capacidade de inovação no que diz respeito à composição dos seus arranjos florais; no entanto, caracterizam-se como tomadores de risco com a capacidade de resolver problemas. Finalmente, o perfil sociocultural demonstra a colaboração entre floristas-intermediários-produtores; tal atividade empresarial gera incentivos económicos com influência local-regional. Portanto, os floristas precisam reforçar os seus laços com outros floristas, produtores e distribuidores para melhorar as suas capacidades inovadoras que beneficiarão tanto eles próprios como os consumidores.

Palavras-chave: empresários, inovação, Rosa spp., floristas, arranjos florais.

\section{Introduction}

In Mexico, flower production is converged in ten municipalities in the southern part of the State of Mexico, which constitute the so-called flower corridor and the main exporting area the most important municipalities are Tenancingo, Coatepec de Harinas and especially Villa
Guerrero (Ramírez and Avitia-Rodríguez, 2017). In 2017, seven ornamentals out of 53 reported, contributed $80.3 \%$ of the total national value while the rose contributes $23.3 \%$ (Siap, 2018). The rose (Rosa spp.) is one of the best known, most cultivated and requested species of cut flower by consumers in Mexico and worldwide due to its beauty, diversity of aromas, shapes and colors and it is

https://doi.org/10.1590/2447-536X.v27i4.2296

"Corresponding author: nrodriguez@uv.mx

Received: Nov 8, 2020 | Accepted: Aug 5, 2021 | Available online: Aug 25, 2021

Licensed by CC BY 4.0 (https://creativecommons.org/licenses/by/4.0/)

Area Editor: Paulo Rodrigo Ramos Xavier Pereira 
also highly appreciated in gardening (Gómez, 2015). It has a long and colorful history as a symbol of love, beauty and is one of the most used by florists in decoration and bouquet arrangement (Reis et al., 2020). In floriculture, the rose plays an important role, since it meets the criteria demanded by the market considering its great popularity (Yong, 2004).

Rose production in the country reached a value of 2,043,522.38 thousand Mexican pesos in 2019. Outstanding production values included the states of Mexico (1,557,774.79), Puebla $(226,888.15)$ and Querétaro $(126,151.60)$ values in thousands of Mexican pesos (Siap, 2019). A portion of what is produced is exported and another one is directed to the national market (Gómez, 2015). This reflects the fact that flower production is an important component that contributes to income and employment generation (Baudoin et al., 2007). However, little attention has been paid, beyond its cultivation, to organizational or innovation topics (Ramírez-Hernández, 2019).

These topics of innovation and employment generation align with the theoretical contributions of Schumpeter. The author conceptualizes the entrepreneur as having sufficient character to go against the current, the mental freedom that is peculiar and rare by nature, the will to achieve social distinction and the desire to prove himself superior to others. Therefore, entrepreneurship is only present when certain economic conditions are favorable, since it drives financial growth (Teran-Yepez and Guerrero-Mora, 2020). Entrepreneurship, understood as the creation of new businesses for self-employment, has become one of the main ways of generating income in developing economies, such as those of Latin America (Querejazu, 2020). This is reflected in the traits of the floricultural entrepreneur in Mexico and the innovative capacity (Ramírez-Hernández, 2019).

The information gap with respect to flower entrepreneurs in Mexico is directly related to the lack of knowledge of the problems that occur in marketing and transportation conditions, from the production systems to the market and storage (Pereira et al., 2018). Thus, within the marketing area, it is necessary to know the variables that influence the florist/distributor and florist/consumer relationship, as it allows a comprehensive view of positive and critical points (Ceratti et al., 2007).

In this process, the activities of retail florists are indispensable elements, Linares-Gabriel et al. (2017) have described the activity of florists and their innovative openness towards new varieties of flowers. Further analysis is still needed with respect to the key entrepreneurs in the commercialization of roses: the florists. This information can be useful to florists to have a panorama regarding the commercial demands of their work. Considering the symbolic and economic importance and the lack of information, the objective of this research was to know the entrepreneurial role of florists in the commercialization of roses (Rosa spp.) in southern Veracruz, Mexico.

\section{Materials and Methods}

The study was conducted in the south region of the state of Veracruz, Mexico, particularly in the cities of Coatzacoalcos, Minatitlán and Acayucan. These cities hold great importance in this region due to their strategic location, trade and services. The three of them are considered metropolitan areas taking into account the number of inhabitants. In addition to this, they are located along the federal highway 185 that connects Coatzacoalcos (state of Veracruz) and Salina Cruz in the state of Oaxaca (Sct, 2013).

Coatzacoalcos municipality borders the following municipalities: Pajapan, Agua Dulce, Moloacán, Ixhuatlán del Sureste and Nanchital de Lázaro Cárdenas del Río (Sefiplan, 2016b). Minatitlán borders the municipalities of Cosoleacaque, Ixhuatlán del Sureste, Moloacán, Las Choapas, Uxpanapa and Hidalgotitlán (Sefiplan, 2016c). The municipality of Acayucan borders Hueyapan de Ocampo, Soteapan, Soconusco, Oluta, Sayula de Alemán and San Juan Evangelista (Sefiplan, 2016a). Hence, the area of influence of the flower shops covers 16 municipalities in total.

An exploratory research was conducted in 20 flower shops, five in Coatzacoalcos, nine in Minatitlán and six in Acayucan. The data was collected through a survey in which florists were interviewed from January to July 2019 using a questionnaire as a tool. The design of the questionnaire was structured with closed and open questions related to marketing aspects and the florists> perceptions regarding consumer preferences the florist/distributor and florist/ consumer relationship. The criteria mentioned by RamírezHernández (2019) were used and the categories are described in Table 1. 
Table 1. Description of categories used to analyze the innovative entrepreneurial profile of florists in southern Veracruz, Mexico

\begin{tabular}{|c|c|c|}
\hline Category & Subcategory & Description \\
\hline Demographic profile & Socioeconomic aspects & $\begin{array}{c}\text { Age, educational variables and experience as factors of suc- } \\
\text { cess in exploiting entrepreneurial opportunities }\end{array}$ \\
\hline Psychosocial profile & $\begin{array}{c}\text { Perception on colors and shapes } \\
\text { of arrangements with rose floral } \\
\text { sticks and vase life }\end{array}$ & $\begin{array}{c}\text { Attributes of originality and innovation, moderate risk aver- } \\
\text { sion and acceptance of their responsibilities }\end{array}$ \\
\hline Socio-cultural profile & $\begin{array}{c}\text { Marketing channel and dates of } \\
\text { commercial importance }\end{array}$ & $\begin{array}{c}\text { Dynamic capabilities through an efficient combination of } \\
\text { organizational resources, showing a strong tendency to } \\
\text { process knowledge through cultural channels }\end{array}$ \\
\hline
\end{tabular}

The data obtained were concentrated in an Excel database and Statistica ${ }^{\circledR}$ version 7 was used for the analysis. First, an exploratory data analysis was performed, using descriptive and graphic techniques. Subsequently, the Kruskal-Wallis (KW) test was used with the quantitative variables to find statistical differences between the groups of flower shops (Acayucan, Coatzacoalcos and Minatitlán) in relation to variables age of the interviewees, years in the trade and number of employees. It was also carried out for the variables frequency of purchase, quantity of purchase and purchase price of rose flower stems. This test was used to test whether a group of data comes from the same population and some data were replaced by categories. This test does not assume normality in the data.

\section{Results and discussion}

\section{Demographic profile}

In relation to the number of interviewees $(n=20)$, it was found a mean age of 42.25 years old, a mean of 19.55 years in business retail and 1.55 mean of employees (Table 2). Regarding the age of the interviewees from Acayucan, the average was 34 years old, from Coatzacoalcos it was 31 and 53 in Minatitlán. The flower shops are attended by the owners, especially in Minatitlán but in Coatzacoalcos and Acayucan the management of the business is in charge of both the owners and employees. The flower shops in Minatitlán have been in business for 30 years while in Coatzacoalcos for 13 years and 9 years in Acayucan.

Table 2. Socioeconomic characteristics of the florists interviewed

\begin{tabular}{|c|c|c|c|c|}
\hline $\mathbf{N}=\mathbf{2 0}$ & Mean & Minimum & Maximum & Standard deviation \\
\hline Age of interviewee & 42.25 & 19.00 & 62.00 & 13.1143 \\
\hline Years in the trade & 19.55 & 2.00 & 45.00 & 14.4348 \\
\hline Employees number & 1.55 & 1.00 & 4.00 & 0.8870 \\
\hline
\end{tabular}

No statistical differences were found in relation to the number of employees when the data were analyzed by groups of flower shops (Acayucan, Minatitlán and Coatzacoalcos). However, for the interviewee's age and years in trade, the Minatitlán sample is significantly different from Coatzacoalcos and Acayucan (Figure 1). This means that florists in this city have been in business for more years than the rest of them. The $55 \%$ of the interviewees are owners and $45 \%$ employees, so the predominant type of employee is the family worker $(65 \%)$, followed by the external worker (35\%). 


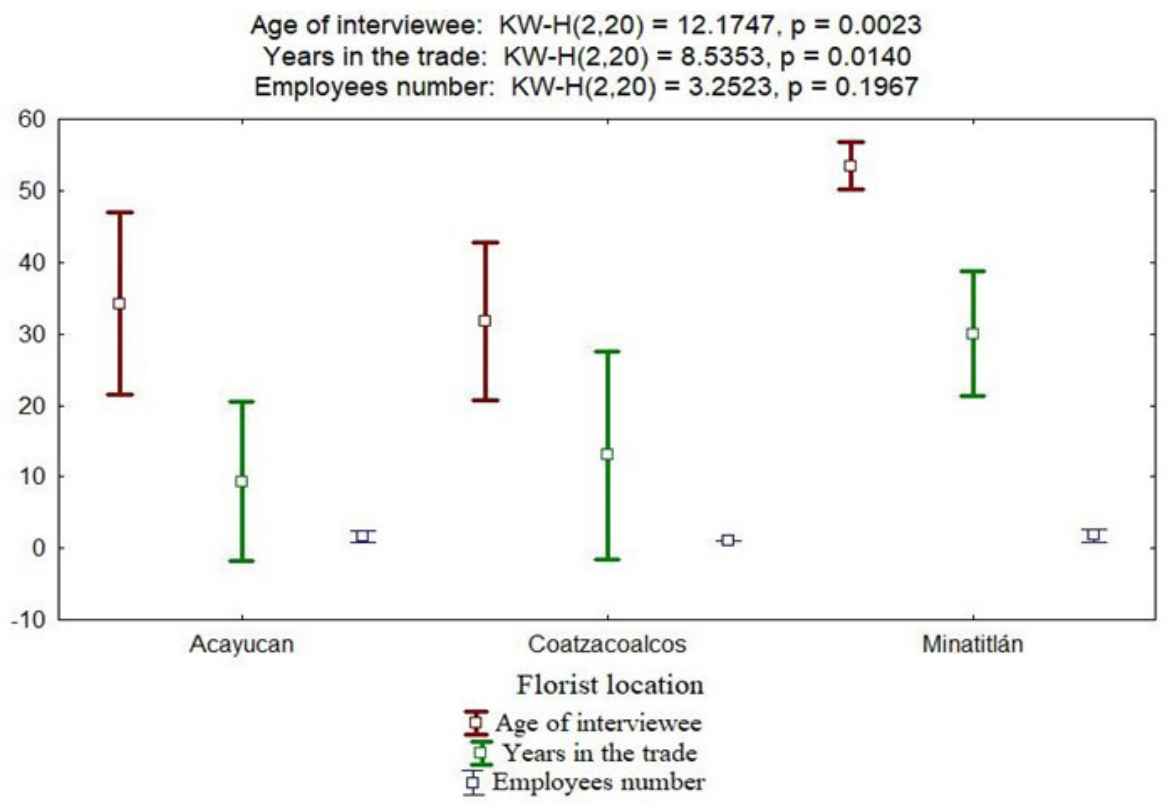

Figure 1. Comparison of the groups of flower shops in relation to the number of employees, age of interviewee and years in the trade (KW $p \leq 0.05)$.

The data shows that time in business corroborates the experience of florists as a factor of entrepreneurial success (Ramírez-Hernández, 2019). The age ranges obtained are similar to what was found by Tejeda-Sartorius et al. (2015). The researchers state that florists in the state of Mexico are younger, most are between 15 and 30 years old (41\%) and between 31 and 45 years old (31\%). The age of the florists shows that the economic activity has a family business orientation due to its main characteristic of self-employment. This according to the stratification of companies, the size of family businesses is "micro" when the number of workers is less than 10 (González-Garfias and Aguilera-Alejo, 2020).

The results are similar to other studies carried out in retail stores in which most of the flower shops are more than 6 years old and are traditional establishments (Ceratti et al., 2007). A study conducted by Reis et al. (2020) shows the relationship between the length of time from 5 to 10 years with the sale of these products. In the same way, the floriculture business initiative is acknowledged as a "family business" due to the self-affinity and potential of this sector. This is a key point for the mortality of a company in the transfer from the first to the second generation. The idea in particular that the company that has always been generating profits and income will always continue to produce capital (González-Garfias and Aguilera-Alejo, 2020).

\section{Psychosocial profile}

The entrepreneur is considered to present attributes of originality and innovation (Ramírez-Hernández, 2019) and one of the factors that contribute to the success of the entrepreneur is experience. Important qualities such as vision, passion, integrity, drive and risk taking are emphasized (Castro et al., 2015). For this reason, it was necessary to know the perception that florists have of their consumers when choosing roses. In that sense, florists assume that consumers prefer the color red, being this the dominant color with $50 \%$ of floral rose sticks purchased. The color white has a preference of $15 \%$, pink and yellow have $12.5 \%$, while $7.5 \%$ prefer the color orange. Finally, a minor fraction selected shaded colors, blues and purples.

It should be noted that roses are one of the most used flowers by florists in decoration and bouquet composition (Reis et al., 2020). Therefore, knowing the color preference of roses is important for the florist, taking into consideration his role of a risk taker. Therefore, the increment in sales is strongly related to consumer preferences that reduces the risk and ensures the sale of the product.

The main forms of commercialization of this type of flowers are the floral arrangement (small, medium and large), the presentation in bouquets and individual stems. This is similar to the florists in the state of Mexico where the most common form of sale is in floral arrangements $(86 \%)$ and in smaller proportion in bouquets $(50 \%)$ or stems (45\%) (Tejeda-Sartorius et al., 2015). Besides, the size of the arrangements and bouquets depends largely on the occasion (Mother's Day or birthday party) as well as the price range in such floral arrangements that costs from 4.85 to 12.34 USD. In the city of Puebla, Mexico, the arrangements in the markets and flower shops have different shapes (fan, round, horizontal, triangular). According to the size, the prices fluctuate from 3.01 to 5.01 USD for the simple size, 5.01 to 11.52 USD for the medium size and 11.52 to 30.06 USD for the big arrangement (TlahuextlTlaxcalteca et al., 2005).

Florists have experienced the main characteristic of an entrepreneur but only a minority of florists have some specialization in the field. Consequently, there is a low degree of product differentiation (Ceratti et al., 2007). Some florists offer photographs of arrangements for 
different occasions, sometimes these arrangements are of incomparable beauty, but in many cases the common arrangements are identical and lack creativity (Tlahuextl-Tlaxcalteca et al., 2005). Therefore, it is necessary for florists to implement consumermarketing strategies, create new forms of design and organization of arrangements and vases. They should orient their actions to the needs of consumers according to different targets: marriage ceremonies, cultural and religious events, and even business and economic aspects (Anacleto et al., 2017).

Product knowledge supports the work of florist, considering that the average vase life of rose flower sticks is five days. For this reason, when sourcing, florists prefer button sticks $(60 \%)$ given that these tend to have a longer vase life and gradually open. In contrast, 35\% of the florists consider the point of flower opening to be indifferent and only 5\% mentioned that they buy the open flower. It is important to have a record of vase life that have an impact on the florists' economy. Therefore, some studies suggest the use of hydrogen $\left(\mathrm{H}_{2}\right)$ in the senescence of roses that, if applied exogenously, could improve the vase life and postharvest quality (Ren et al., 2017). Apart from that, the use of pulse solutions with roses, particularly the Vendela cultivar, stems can reach up to 13 days of longevity (Mosqueda-Lazcares et al., 2011). Some authors recommend dry handling of rose stems (Freedom, Opera, Red alfa and Red vicer) after refrigerated storage to extent their storage life up to 21 days, reduce costs and maintain the final quality of the flower (Mosqueda-Lazcares et al., 2012).

Even though there is a margin in vase days mentioned by interviewees and available information suggesting alternatives that lower costs and extend the life of roses in vases, the florists interviewed do not have adequate training to implement these strategies. Therefore, it is important that they receive training (courses and workshops) on the care of plants in decorative vases to maintain the quality of flowers at the point of sale. Additionally, it is suggested to offer courses or services that can increase customer interest in the care of flowers and ornamental plants (Paiva et al., 2020).

Considering that creativity is also a basic characteristic of the floricultural entrepreneur (RamírezHernández, 2019), it is necessary for flower shop owners to participate in exhibitions and congresses. They also need to consult specialized books and keep themselves constantly updated in order to provide better customer service (Reis et al., 2020).

\section{Sociocultural profile}

Action for self-employment purposes is understood as a process in which the economic agent is responsible for all the consequences of the risk and uncertainty they face by their decisions in a given economic context (Querejazu, 2020). These risks are assumed by the florist when deciding who to buy from, how much to buy at what price or the moment of purchasing the product, which is indispensable in the rose marketing channel. In this direction, the dynamic capabilities of florists are demonstrated through an efficient combination of their organizational resources (RamírezHernández, 2019).

Actually, most of the roses sold in southern Veracruz come from the State of Mexico (57.14\%), followed by Puebla (25\%) and Chiapas (17.86\%). The florists mentioned that, although they are more expensive, they prefer them because they have a better quality. According to the data provided by the florists (florist/producer), the roses they purchase are produced under greenhouses and the maximum sales volume among the three cities is around $1,043,925$ rose flower sticks per year. It can be inferred that the entrepreneurial activity of the flower shops in these cities generates economic incentives with local-regional influence.

Furthermore, no statistical differences were found between the groups of flower shops with respect to the variables of purchase frequency, purchase quantity and purchase price (Figure 2). At the time of purchase and sale, $100 \%$ of the florists purchase packs of 25 floral sticks of roses each. They buy from 30 to more than 100 packs per day, since this is the only way in which they are marketed by producers and/or intermediaries. It is important to mention that the average market price per rose package at the national level is 2.51 USD (Quevedo et al., 2020). In financial terms, this is equivalent to a minimum amount of 75.17 USD and a maximum of 250.56 USD per day.

The prices and quantity of packages of floral sticks purchased are closely linked to the dates of high and low demand. Florists purchase more packages on specific dates, mainly because of cultural traditions in Mexico. Consequently, the willingness to pay depends on the income and the perception of quality that consumers have about roses, due to the fact that they are perceived as a luxury product (Quevedo et al., 2020). 


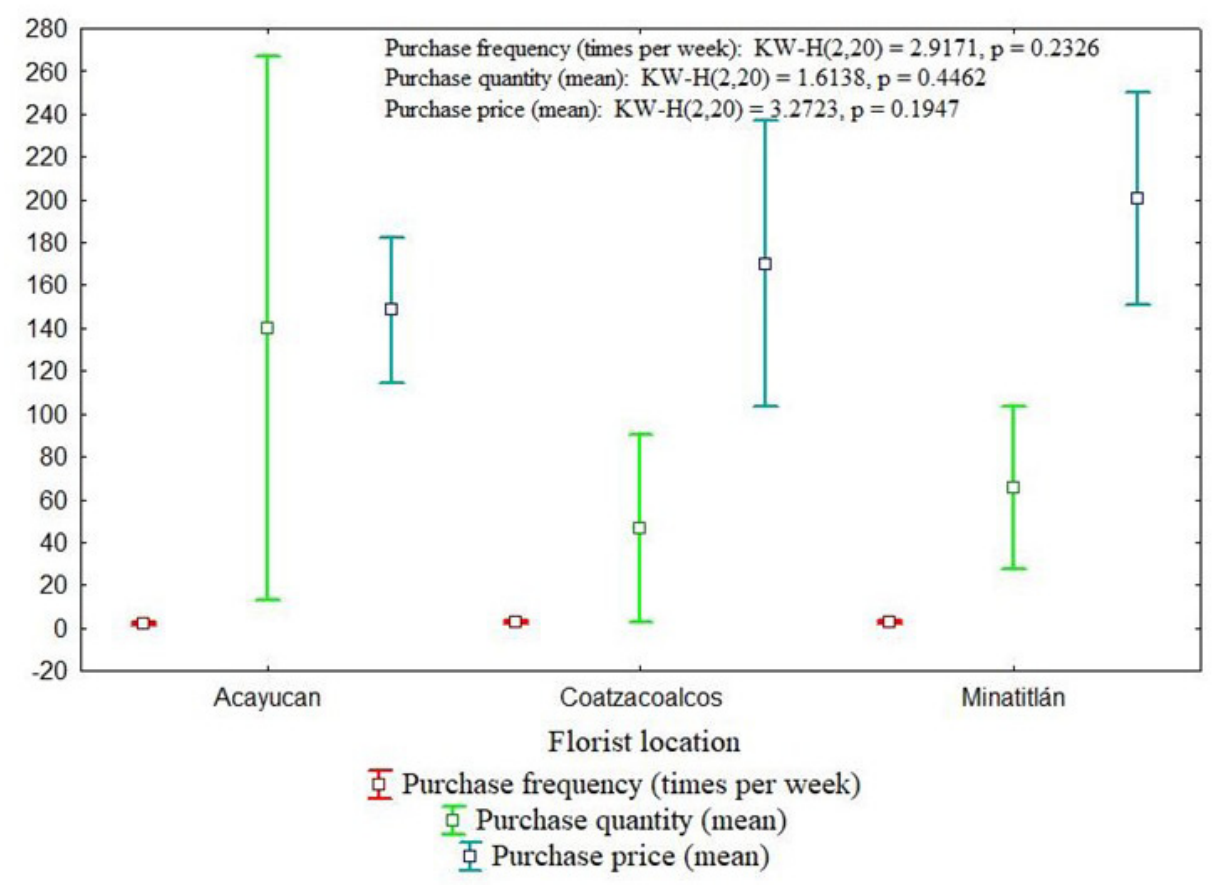

Figure 2. Comparison of the flower shop groups in relation to the frequency of purchase, purchase quantity and purchase price of roses (KW $p \leq 0.05)$.

Considering the quality and perishability of roses, transportation is an important segment to avoid losses (Paiva, 2018). Nevertheless, 50\% of florists buy from an intermediary seller, $35 \%$ directly from producers and only $15 \%$ buy from both. In regards to the purchase of flowers (florist/producer), this coincides with Linares-Gabriel et al.
(2017) results from the same states of the country. It should be recalled that the area of influence of the flower shops covers 16 municipalities whose population is a potential market for the commercialization of floral arrangements or small intermediaries who purchase flower stems for resale (Figure 3).

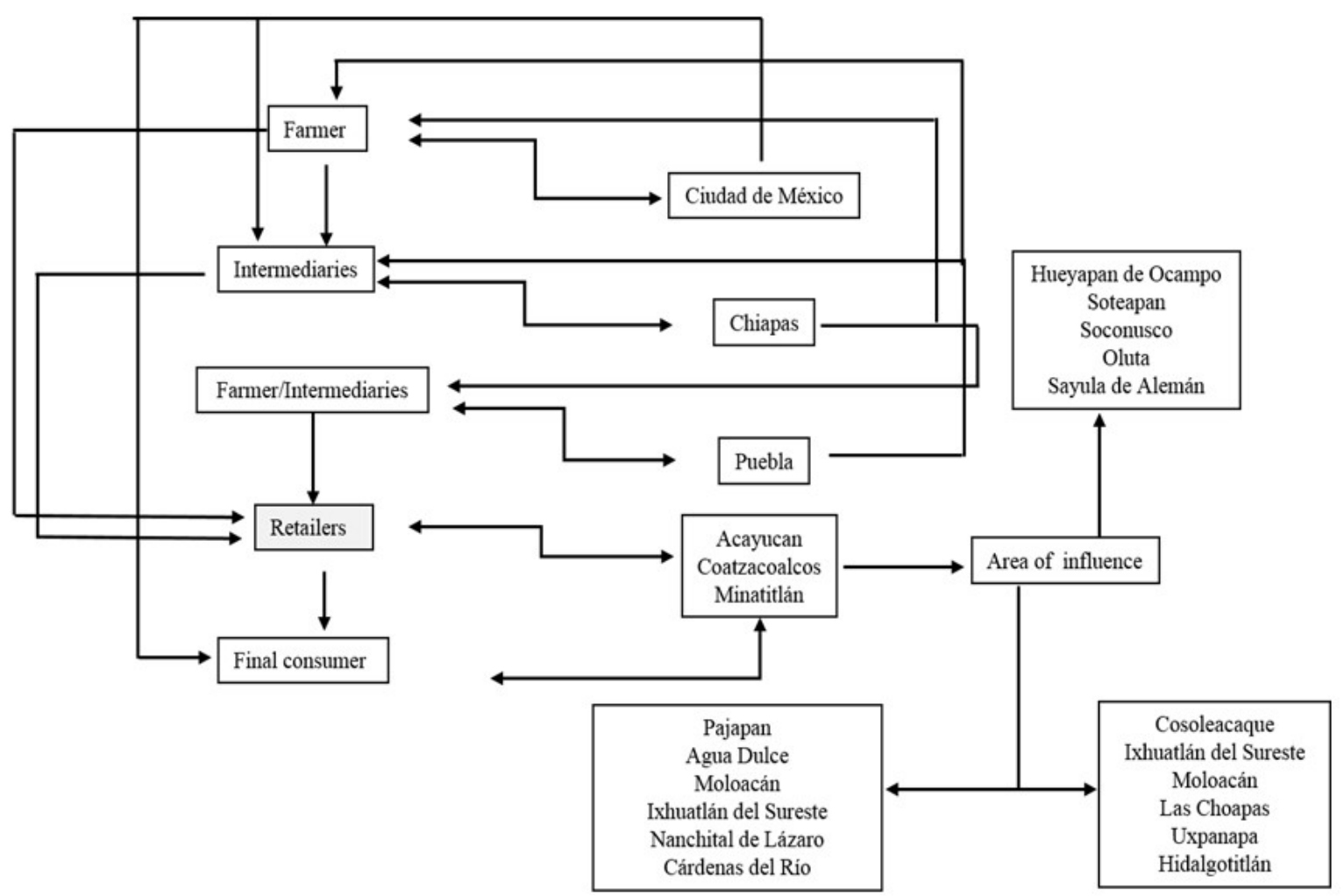

Figure 3. Commercialization channel of roses and area of influence of the three cities 
The sale of flowers in these cities plays a significant role in the regional economic dynamics. Influenced by this, the activity is located in a flower market segment that requires cutting-edge criteria. That is to say, to develop the prototype of a pleasant store, visually and emotionally, as well as using distinctive flowers, plants and arrangements to increase varieties to place in-store displays and brochures. Besides that, it can be beneficial to present gift ideas to people, organize events, fairs, etc. Moreover, taking into account the area of influence, it is essential to develop a website to minimize labor costs and receive online orders (Ara and Hosen, 2017). Producers, florists and distributors must certainly gain a better understanding of what consumers are looking for, and thus, establish strategies in order to encourage the consumption of good quality products (Quevedo et al., 2020). For this reason, the florist is recognized as a floricultural entrepreneur with the capacity to solve the problems that arise (RamírezHernández, 2019).

In developing economies there is more entrepreneurial activity than in developed economies (Querejazu, 2020), this is reflected in the dates of commercial importance for florists. This implies an increase in the sale of floral arrangements, especially roses. The color of the roses is a key point to know the days of highest sales. Florists mentioned that the day with the highest sales are May $10^{\text {th }}$ and Valentine's Day (February 14th). In terms of cultural aspects at national level, the most demanded type of flower product is the rose (Tejeda-Sartorius et al., 2015).

These dates are of greater purchases to producers and intermediaries leading to an increase in the price of the product. Most importantly, this generates an increase in the price for the final consumer, for instance, the cost of a floral rose stick amounts to 2 USD. The dates of commercial importance are related to other studies that show that consumers buy floral arrangements for gifts on Mother's Day and Valentine's Day, selecting roses as the main gift (Anacleto et al., 2017; Paiva et al., 2020). In the city of Puebla, Mexico, roses are sold mostly on Valentine's Day and New Year's Day (Tlahuextl-Tlaxcalteca et al., 2005). In flower shops of the State of Mexico, Mother's Day is the time with the highest sales (82\%), followed by December 12, Day of the Dead and February 14 (Tejeda-Sartorius et al., 2015).

Nowadays, the work of these entrepreneurs can definitely be acknowledged as the basis of the national economy. Provided they are formally registered, they generate employment, professional and human development. Therefore, in the era of rising unemployment, the so-called MiPyMEs (Micro, Small and Medium Enterprises) are an option for self-employment and income (González-Garfias and Aguilera-Alejo, 2020).

\section{Conclusions}

This study shows that roses are a product of economic and symbolic importance to flower shops in southern Veracruz, Mexico. Florists are positioned as entrepreneurs based on the demographic, psychosocial and sociocultural profile since they drive economic growth.
The demographic profile shows that these economic agents have the necessary experience and knowledge to develop in their activity. Florists are identified as family micro-entrepreneurs. The psychosocial profile shows that florists are characterized as risk takers who are responsible for their decisions.

The sociocultural profile shows that there is collaboration between florists-intermediary-producers. In line with this, the entrepreneurial activity of the flower shops generates economic incentives with local-regional influence. Consequently, florists need to strengthen their links with other florists, producers and distributors to strengthen their innovative capabilities.

The importance of specific dates in increasing sales is evident; this contributes not only to the increase in income for florists but also for intermediaries and producers. These findings indicate the potential that florists have and open an opportunity for the use of available technologies to increase the vase life, create new floral styles and designs, and encourage local-regional events of florists to expand their network of consumers. In addition, it is evident that roses are in great demand in this region, so the information gathered is useful for florists or producers in the region who are interested in rose production. In this way, the distribution channel can be facilitated, purchase and sale prices can be lowered, and the quality of the product can be improved.

\section{Author Contribution}

NRO: contributed to the research design, data analysis and writing of the manuscript. EVA: contributed in the collection and analysis of data, and writing of the manuscript. ALG: contributed in the theoretical approach to the research, data analysis and writing of the manuscript. MAHC: contributed to the systematization of information, data analysis and writing of the manuscript.

\section{References}

ANACLETO, A.; NEGRELLE, R.R.B.; CUQUEL, F.L.; MURARO, D. Profile and behavior of flower consumer: subsidies for marketing actions. Revista Ceres, v.64, p.557-566, 2017. http://dx.doi.org/10.1590/0034$737 \times 201764060001$.

ARA, H.; HOSEN, M.M. Exploring the floral marketing practices: an investigation of the retail floral traders of Bangladesh. European Journal of Business and Management, v.9, p.28-38, 2017.

BAUDOIN, W.; BESTER, C.; CHEMONIDOU, D.; LAWS, N.; MOHKTARI, M.; OZZAMBAK, E. Floriculture for food security. Acta Horticulturae, v.743, p.25, 2007.

CASTRO, B.; ALBERTO, M.; SAAVEDRA GARCÍA, M.L.; CAMARENAADAME, M.E. Hacia una comprensión de los conceptos de emprendedores y empresarios. Suma de Negocios, v.6, p.98-107, 2015. 
CERATTI, M.; PAIVA, P.D.O.; SOUSA, M.D.; TAVARES, T.S. Comercialização de flores e plantas ornamentais no segmento varejista no município de Lavras/MG. Ciência e Agrotecnologia, v.31, p.1212-1218, 2007.

GÓMEZ, A.A.G. Producción y comercialización de rosa en México. In: PÉREZ-SOTO, F.; FIGUEROAHERNÁNDEZ, E., (Eds.). Ciencias Sociales: Economía y Humanidades: Handbook. Texcoco de Mora: ECORFAN, 2015. p.1-11.

GONZÁLEZ-GARFIAS, R.; AGUILERA-ALEJO, G. Las empresas familiares como base en el desarrollo económico local en el estado de San Luis Potosí. Vincula Tégica EFAN, v.1, p.812-829, 2020.

LINARES-GABRIEL, A.; VELASCO-VELASCO, J.; RODRÍGUEZ-OROZCO, N.; TINOCO-ALFARO, C.; HERNÁNDEZ-CHONTAL， M.; LÓPEZ-COLLADO, C. Comercialización de heliconias (Heliconia L.) en Acayucan, Veracruz, México. Agroproductividad, v.10, p.56-61, 2017.

MOSQUEDA-LAZCARES, G.; ARÉVALO-GALARZA, L.; VALDOVINOS-PONCE, G.; RODRÍGUEZ-PÉREZ, J.E.; COLINAS-LEÓN, M. Manejo y almacenamiento en seco y húmedo de cuatro cultivares de rosa de corte. Revista Chapingo. Serie Horticultura, v.18, p.317-323, 2012.

MOSQUEDA-LAZCARES, G.; ARÉVALO-GALARZA, M.D.L.; VALDOVINOS-PONCE， G.; RODRÍGUEZPÉREZ, J.E.; COLINAS-LEÓN, M.T. Época de corte y manejo poscosecha de ocho cultivares de rosa de corte. Revista Mexicana de Ciencias Agrícolas, v.2, p.591-602, 2011.

PAIVA, P.D.O. Horticulture and ornamental horticulture. Ornamental Horticulture, v.24, p.6, 2018. https://doi. org/10.14295/oh.v24i1.1169

PAIVA, P.D.O.; REIS, M.V.D.; SANT'ANA, G.S.; BONIFÁCIO, F.D.L.; GUIMARÃES, P.H.S. Flower and ornamental plant consumers profile and behavior. Ornamental Horticulture, v.26, p.333-345, 2020. https:// doi.org/10.1590/2447-536x.v26i3.2158

PEREIRA, M.S.; FERRAZ, M.V.; GASPAROTO, M.C.D.G.; OLIVEIRA, T.D. A survey on the transport conditions and storage of roses (Rosa spp.) commercialized at CEAGESP flower wholesale in São Paulo City, Brazil. Ornamental Horticulture, v.24, p.125-137, 2018. https:// doi.org/10.14295/oh.v24i2.1166.

QUEREJAZU, V.C.V. Aproximación teórica a las causas del emprendimiento. Economía: teoría y práctica, p.6997, 2020. http://dx.doi.org/10.24275/etypuam/ne/522020/ Querejazu.
QUEVEDO, D.R.N.; RODRÍGUEZ, J.A.A.; HERNANDÉZ, J.J.R. Rosa de corte mexicana: disponibilidad a pagar del consumidor y su percepción de calidad. Panorama Económico, v.28, p.80-93, 2020. https://doi.org/10.32997/pe-2020-2690.

RAMÍREZ, H.J.J.; AVITIA-RODRÍGUEZ, J.A. Floricultura mexicana en el siglo XXI: su desempeño en los mercados internacionales. Revista de Economía, v.34, p.99-122, 2017.

RAMÍREZ-HERNÁNDEZ, J.J. Floricultura en el sur mexiquense: rasgos del emprendedor que inciden en la capacidad empresarial de innovación. Revista de Investigación en Ciencias Contables y Administrativas, p.4, 2019.

REIS, M.V.D.; SANT'ANA, G.S.; PAIVA, P.D.O.; BONIFÁCIO, F.D.L.; GUIMARÃES, P.H.S. Profile of producer and retailer of flower and ornamental plant. Ornamental Horticulture, p.26, v.367-380, 2020. https:// doi.org/10.1590/2447-536x.v26i3.2164

REN, P.-J.; JIN, X.; LIAO, W.-B.; WANG, M.; NIU, L.-J.; LI, X.-P.; XU, X.-T.; ZHU, Y.-C. Effect of hydrogen-rich water on vase life and quality in cut lily and rose flowers. Horticulture, Environment, and Biotechnology, v.58, p.576-584, 2017. 10.1007/s13580-017-0043-2.

SCT. Índice Red Carreteras. México: Secretaría de Comunicaciones y Transportes Dirección General de Servicios Técnicos, 2013. 60p.

SEFIPLAN. Cuadernillos municipales 2016 Acayucan. p. Secretaría de Finanzas y Planeación del Estdo de Veracruz, 2016a. Available at: <http://ceieg.veracruz.gob. $\mathrm{mx} / \mathrm{wp}$-content/uploads/sites/21/2016/05/Acayucan.pdf $>$.

SEFIPLAN. Cuadernillos municipales 2016 Coatzacoalcos. p. Secretaría de Finanzas y Planeación del Estdo de Veracruz, 2016b. <http://ceieg.veracruz.gob.mx/ wp-content/uploads/sites/21/2016/05/Coatzacoalcos.pdf >.

SEFIPLAN. Cuadernillos municipales 2016 Minatitlán. p. Secretaría de Finanzas y Planeación del Estdo de Veracruz, 2016c. Available at: <http://ceieg.veracruz.gob.mx/wpcontent/uploads/sites/21/2016/05/Minatitl\%C3\%A1n.pdf >.

SIAP. Anuario Estadístico de la Producción Agrícola. p. Servicio de Información Agroalimentaria y Pesquera Acciones y Programas Cierre de la producción agrícola, 2019. Disponível em: $<$ https://nube.siap.gob.mx/cierreagricola/ $>$.

SIAP. Ornamentos: ¿de cuál regalas tú? Compartiendo la belleza del campo mexicano. $p$. Servicio de Información Agroalimentaria y Pesquera, 2018. Available at: $<$ https:// www.gob.mx/siap/es/articulos/ornamentos-de-cualregalas-tu?idiom $=\mathrm{es}>$. 
TEJEDA-SARTORIUS, O; RÍOS-BARRETO, Y.; TLAHUEXTL-TLAXCALTECA, C.; ÁVILA-SANCHEZ, TREJO-TÉLLEZ, L.I.; VAQUERA-HUERTA, H. J.; LESZCZYÑSKA-BORYS, H. Flores de corte y follaje Caracterización de la producción y comercialización de en florerías y mercados de Puebla, México. Revista flor de corte en Texcoco, México. Revista Mexicana de Chapingo Serie Horticultura, v.11, p.323-327, 2005.

Ciencias Agrícolas, v.6, p.1105-1118, 2015.

TERAN-YEPEZ, E.; GUERRERO-MORA, A.M. Teorías de emprendimiento: revisión crítica de la literatura $\mathrm{y}$ YONG, A. El cultivo del rosal y su propagación. Cultivos Tropicales, v.25, p.53-67, 2004. sugerencias para futuras investigaciones. Revista Espacios, p.41, 2020. 